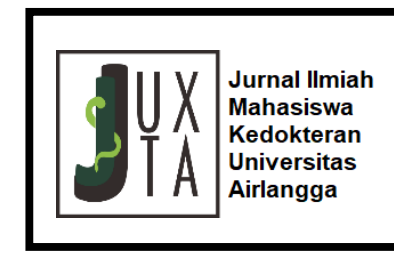

\title{
NICU Healthcare Workers Hand Hygiene Compliance during 6 Months of Direct Observation
}

\author{
Inna Fairuuza Firdaus ${ }^{1}$, Dwiyanti Puspitasari ${ }^{\star}{ }^{\star}$, Marijam Purwanta $^{3}$
}

${ }^{1}$ Faculty of Medicine, Universitas Airlangga, Surabaya, Indonesia.

${ }^{2}$ Department of Pediatrics, Faculty of Medicine, Universitas Airlangga - Dr. Soetomo General Hospital Surabaya, Indonesia. ${ }^{3}$ Department of Microbiology, Faculty of Medicine, Universitas Airlangga - Dr. Soetomo General Hospital Surabaya, Indonesia.

\section{A B S TR A C T}

Introduction: Hospitalized neonates are at risk of developing nosocomial sepsis, a systemic infection due to unhygienic healthcare, especially in Indonesia where healthcare-associated infection incidence rate is $5.9 \%-8.3 \%$. Hand hygiene by healthcare workers is an effective measure to prevent it. This study aimed to understand the healthcare workers' hand hygiene compliance towards WHO guidelines 2009 in Dr. Soetomo General Hospital NICU.

Methods: This research was an observational study. The healthcare workers' hand hygiene compliance was obtained through 6 months of direct observation, from November 2018 to April 2019, with doctors and nurses who agreed to be observed and present during the observation period as samples. The observation was recorded with WHO observation form, and processed with Microsoft Excel 2013 to obtain compliance rate.

Results: Overall, the compliance of healthcare worker in NICU Dr. Soetomo General Hospital during the 6 months of study was $84 \%$. Nurses' compliance was higher $(87 \%)$ than doctors' $(78 \%)$. Compliance to My 5 Moments of Hand Hygiene indications varied from $82 \%$ for moments before patient contact to $93 \%$ for moments after patient contact.

Conclusion: In conclusion, hand hygiene compliance of healthcare workers in Dr. Soetomo General Hospital NICU varied between profession categories and each indication. To maintain and improve hand hygiene compliance, intervention in healthcare workers' behavior is needed, so that healthcare-associated infection can be better prevented.

* Correspondence: dwiyanti-p@fk.unair.ac.id

JUXTA: Jurnal IImiah Mahasiswa Kedokteran Universitas Airlangga

p-ISSN: 1907-3623; e-ISSN: 2684-9453

DOI: 10.20473/juxta.V11|12020.41-44

Open access under Creative Commons Attribution-ShareAlike 4.0 International License

(CC-BY-SA)
ARTICLE INFO

\author{
Article history: \\ Received 30 October 2019 \\ Received in revised form 06 \\ January 2020
}

Accepted 26 January 2020

\section{Keywords:}

Hand hygiene,

Observation,

Healthcare-associated infection, Healthcare. 


\section{Introduction}

Each year, 5.3 million children under the age of 5 died with the majority occurred during the neonatal period. The main cause of death in developing countries, including Indonesia, is infection which may be transmitted horizontally due to unhygienic healthcare. ${ }^{1}$ Failure in maintaining hygiene in the healthcare setting may cause healthcare-associated infection, especially in hospitalized neonates, due to their immature immune system. ${ }^{2}$

Healthcare-associated infection (HAl) is linked to the increase in mortality, morbidity, healthcare cost, and antimicrobial resistance. Intensive care is associated with higher $\mathrm{HAl}$ incidence rate, due to invasive instrumentation and procedure, ${ }^{3} \mathrm{HAl}$ incidence rate varied worldwide in Neonatal Intensive Care Unit (NICU), from $19.7 \%$ in Saudi Arabia $^{4}$ to $71 \%$ in a study in India. In Indonesian hospitals, the reported $\mathrm{HAI}$ rate are $5.9 \%-8.3 \% .^{5}$ However, the study by Zaidi, et al. reported the rate of $\mathrm{HAI}$ in one $\mathrm{NICU}$ in Indonesia is as high as $51-52 \%$ of the admitted neonates. ${ }^{6}$

One of the means to reduce $\mathrm{HAl}$ is by practicing hand hygiene. Good hand hygiene practice reduce the risk of $\mathrm{HAl}$ by preventing pathogen transmission from the healthcare area to the patient through the healthcare workers' hands ${ }^{7}$. In 2009, WHO had issued Guidelines on Hand Hygiene in Health Care. Yet, the healthcare workers' hand hygiene compliance towards WHO guideline is still vary around the world. ${ }^{7}$ A study in an emergency department of an Indonesian hospital stated nurses' hand hygiene compliance was $30 \%,{ }^{8}$ and in an Indian Hospital NICU, the healthcare workers' hand hygiene compliance was $46 \%{ }^{3}$

The healthcare workers' hand hygiene compliance varies, but, to our knowledge, there are still no publication regarding the topic in NICU of Dr. Soetomo General Hospital. Therefore, the aim of this study was to understand the healthcare workers' hand hygiene compliance towards WHO guideline 2009 in Dr. Soetomo General Hospital Emergency Department NICU.

\section{Methods}

This was an observational study, with the samples of doctors and nurses in Dr. Soetomo Emergency Department NICU who agreed to be observed and present during the observation period. The study was conducted in a level III NICU of a tertiary hospital with 20 beds. At the time of this study, the existing hand hygiene policy was based on WHO guideline on hand hygiene practice in healthcare in $2009 .{ }^{7}$ Alcohol hand rub dispenser was provided at every bed, and 6 sinks for hand wash were available in the unit.

Healthcare workers' hand hygiene compliance were obtained from direct observation by observer trained by $\mathrm{Dr}$. Soetomo General Hospital Infection Control Team and recorded with $\mathrm{WHO}$ hand hygiene observation form ${ }^{9}$. The observation was conducted from November 2018 to April 2019. The observations were done for WHO My 5 moments hand hygiene indications: 1) before touching the patient, 2) before aseptic procedures, 3 ) after contact with body fluids, 4) after touching the patient, and 5) after touching the patient's surroundings. The presence of one or more indications of hand hygiene is defined as hand hygiene opportunity. Healthcare workers' action towards hand hygiene opportunity may be performed, either by hand rubbing with alcohol-based hand rub or handwash with water and soap, or missed.

The recorded observations were: profession categories (doctors or nurses), hand hygiene action (performed or missed), hand hygiene technique (hand wash or hand rub), and gloves usage. The observation was conducted once a week, each session lasted for 30-40 minutes, on a randomized time by simple random sampling to avoid bias related to time. To reduce Hawthorne effect, where the subject was aware that he/she was being observed, the observer remained unobtrusively as possible while still allowing an unobstructed view of the healthcare workers' hand hygiene activities. This study was approved by Dr. Soetomo General Hospital's ethical committee. Data on healthcare workers' hand hygiene compliance was collected during the study, then processed with Microsoft Excel 2013 to obtain compliance rate.

\section{Results}

Throughout 6 months of study, a total of 412 hand hygiene opportunities were obtained during 27 observation sessions. Overall, Emergency Department NICU healthcare workers' hand hygiene compliance was $84 \%$ (347/412). By each profession category, NICU nurses had higher hand hygiene compliance rate than the doctors $(87 \%$ vs. $78 \%$ ) (Table 1.).

Table 1. Comparison of hand hygiene compliance by profession category.

\begin{tabular}{|l|l|l|l|}
\hline Profession & Action & Opportunity & Compliance \\
\hline Doctors & 120 & 93 & $78 \%$ \\
\hline Nurses & 254 & 292 & $87 \%$ \\
\hline Overall & 412 & 347 & $84 \%$ \\
\hline
\end{tabular}

The healthcare workers' compliance towards My 5 Moments of Hand Hygiene indications varied, with the highest compliance of $93 \%$ for moments after touching the patients. Moments before touching the patient had the lowest compliance, which was only $82 \%$ (Table 2.).

Table 2. Healthcare workers' compliance towards My 5 Moments of Hand Hygiene indications.

\begin{tabular}{|llll|}
\hline Indication & Opportunity & $\begin{array}{c}\text { Performed } \\
\text { Action }\end{array}$ & Compliance \\
\hline $\begin{array}{l}\text { Before } \\
\text { touching the } \\
\text { patient }\end{array}$ & 181 & 148 & $82 \%$ \\
\hline $\begin{array}{l}\text { Before aseptic } \\
\text { procedures }\end{array}$ & 40 & 35 & $88 \%$ \\
\hline $\begin{array}{l}\text { After contact } \\
\text { with body fluid }\end{array}$ & 54 & 50 & $93 \%$ \\
\hline $\begin{array}{l}\text { After touching } \\
\text { the patient }\end{array}$ & 190 & 173 & $91 \%$ \\
\hline $\begin{array}{l}\text { After touching } \\
\text { patient's } \\
\text { surroundings }\end{array}$ & 78 & 90 & $87 \%$ \\
\hline
\end{tabular}

\section{Discussion}

Neonates are susceptible to infection, due to weakness of their skin integrity, fragile mucous, and immature immune system. Hospitalized neonates, especially in NICU, are more prone to $\mathrm{HAl}$ because of invasive instrumentation and procedures. ${ }^{10}$ Pathogens from the healthcare area may be transmitted to the neonates through the healthcare workers' hands during unhygienic medical procedures. One way to prevent HAI is by maintaining good hand hygiene practice. ${ }^{9}$

In this 6 months observation study, the overall hand hygiene compliance of Dr. Soetomo Hospital Emergency Department NICU healthcare workers was $84 \%$. This number is quite high compared to hand hygiene compliance in non-NICU settings in another Indonesian hospital with 
only $30 \%$ compliance rate. ${ }^{8}$ In other NICU settings, the reported hand hygiene compliance ranged from $42 \%{ }^{11}$ to $89 \% .^{12}$

During the study, the nurses' hand hygiene compliance $(87 \%)$ was higher than the doctors $(78 \%)$. This figure is inline with other studies summarized in $\mathrm{WHO}$ guidelines on hand hygiene in 2009. Kowitt, et al. theorized that differences in hand hygiene compliance between nurses and doctors were because of variation in education, work scheme, and staffing structure. Nurses are also thought to have more opportunities to perform hand hygiene, and opportunity cost for doctors to do hand hygiene is higher compared to the nurses. ${ }^{13}$

NICU healthcare workers' compliance towards My 5 Moments of Hand Hygiene in this study ranged from $82 \%$ for moments before touching the patient to $93 \%$ for moments after contact with body fluids. These findings differ from other study in an Asian hospital, where the lowest compliance was moments before aseptic procedures, followed by after contact with patient's surroundings, and before touching the patient. In the aforementioned study, moments after contact with body fluids and after touching the patient had the highest compliance rate, in-line with our study. ${ }^{14}$

Overall, compliance in moments before patient contact (before touching the patient and before aseptic procedures) was generally lower (85\%) than after patient contact $(89 \%)$. Glove usage might hinder hand hygiene performance, especially for moments before aseptic procedures. Healthcare workers tend to perceive that glove usage renders hand hygiene unnecessary before and after usage..$^{9,15}$ Universally, healthcare workers' behavior in hand hygiene tends to be more self-protective rather than patient's safety-centered practice..$^{15}$ This also explained the high compliance in moments after contact with body fluids and after touching the patient in this study. Nevertheless, the healthcare workers tend to not wash their hands after touching the patient's surroundings. This was because of the elective responses of the healthcare workers after touching the patient's surroundings, where they tend to not wash their hand if they feel clean and not visibly dirty. ${ }^{15,16}$

Even though the overall Dr. Soetomo General Hospital Emergency Department NICU healthcare workers' hand hygiene compliance was high, good hand hygiene practice should be further improved and maintained, so that HAl could be properly controlled. Studies showed that monitoring, audit, and feedback are effective in maintaining hand hygiene compliance rate high at a long term. ${ }^{9,14,17}$ To improve hand hygiene compliance, interventions such as hand hygiene education and incentive-giving are proved to increase the healthcare workers' compliance. ${ }^{11,14}$

\section{Conclusion}

Hand hygiene compliance of Dr. Soetomo General Hospital Emergency Department NICU healthcare workers varied between profession categories and each indication. To maintain and improve hand hygiene compliance in healthcare workers, further intervention on the healthcare workers' behavior is needed, so $\mathrm{HAl}$ can be better prevented.

\section{Acknowledgement}

Special thanks to the Head Nurse of Dr. Soetomo Hospital Emergency Department NICU and Infection Control Team for their assistance in this study.

\section{CONFLICT OF INTEREST}

The author stated there is no conflict of interest in this study.

\section{REFERENCES}

1. World Health Organization (WHO). WHO | MDG 4: Reduce Child Mortality [Internet]. WHO. World Health Organization; 2015 [cited 2019 May 6]. Available from: https://www.who.int/topics/millennium_development_goals /child mortality/en/

2. Voller SMB, Myers PJ. Neonatal Sepsis. Clin Pediatr Emerg Med [Internet]. 2016 Jun 1 [cited 2019 Oct 2];17(2):129-33. Available from: https://www.sciencedirect.com/science/article/pii/S152284 0116300064 doi: 10.1016/J.CPEM.2016.03.006

3. Chhapola V, Brar R. Impact of an Educational Intervention on Hand Hygiene Compliance and Infection Rate in a Developing Country Neonatal Intensive Care Unit. Int J Nurs Pract. 2015;21(5):486-92. https://doi.org/10.1111/ijn.12283

4. Mahfouz AA, Al-Azraqi T., Abbag FI, Al-Gamal MN, Seef $S$, Bello CS. Nosocomial Infections in a Neonatal Intensive Care Unit in South-Western Saudi Arabia. East Mediterr Heal J [Internet]. 2010 [cited 2019 Oct 27];16(1):40-4. Available from: http://www.emro.who.int/emhj-volume-162010/volume-16-issue-1/article7.html

5. Duerink DO, Roeshadi D, Wahjono H, Lestari ES, Hadi $\mathrm{U}$, Wille JC, et al. Surveillance of Healthcare-Associated Infections in Indonesian Hospitals. J Hosp Infect. 2006;62(2):219-29.

https://doi.org/10.1016/j.jhin.2005.08.004

6. Zaidi AKM, Huskins WC, Thaver D, Bhutta ZA, Abbas Z Goldmann DA. Hospital-Acquired Neonatal Infections in Developing Countries. Lancet. 2005;365(9465):1175-88. https://doi.org/10.1016/S0140-6736(05)71881-X

7. World Health Organization (WHO). WHO Guidelines on Hand Hygiene in Health Care: First Global Patient Safety Challenge Clean Care is Safer Care [Internet]. Vol. 30. 2009. 270 p. Available from: http://whqlibdoc.who.int/publications/2009/9789241597906 eng.pdf doi: 10.1086/600379

8. Surya Pratama B, Koeswo M, Rokhmad K. Faktor Determinan Kepatuhan Pelaksanaan Hand Hygiene pada Perawat IGD RSUD dr. Iskak Tulungagung. J Kedokt Brawijaya [Internet]. 2015 Apr 1 [cited 2019 May 22];28(2):195-9 Available from: http://jkb.ub.ac.id/index.php/jkb/article/view/954 doi: 10.21776/ub.jkb.2015.028.02.14

9. World Health Organization. Hand Hygiene Technical Reference Manual. Geneva: WHO Press; 2009. 31 p.

10. Higgins RD, Baker CJ, Raju TNK. Executive Summary of the Workshop on Infection in the High-Risk Infant. J Perinatol [Internet]. 2010;30(6):379-83. Available from: http://dx.doi.org/10.1038/jp.2009.199 10.1038/jp.2009.199

11. Pessoa-silva CL, Hugonnet S, Pfister R, Touveneau S, Dharan S, Posfay-barbe K, et al. Reduction of Health Care - Associated Infection Risk in Neonates by Successful Hand Hygiene Promotion. 2007; https://doi.org/10.1542/peds.2006-3712

12. Raskind $\mathrm{CH}$, Worley S, Vinski J, Goldfarb J. Hand Hygiene Compliance Rates After an Educational Intervention in a Neonatal Intensive Care Unit. Infect Control Hosp Epidemiol. 2007;28(09):1096-8. https://doi.org/10.1086/519933

13. Kowitt B, Jefferson J, Mermel LA. Factors Associated with Hand Hygiene Compliance at a Tertiary Care Teaching 
Hospital. Infect Control Hosp Epidemiol. 2013;3(11):1-7. https://doi.org/10.1086/673465

14. Moghnieh R, Soboh R, Abdallah D, El-Helou M, Al Hassan S, Ajjour L, et al. Health Care Workers' Compliance to the My 5 Moments for Hand Hygiene: Comparison of 2 Interventional Methods. Am J Infect Control [Internet]. 2017;45(1):89-91. Available from: http://dx.doi.org/10.1016/j.ajic.2016.08.012 doi: 10.1016/j.ajic.2016.08.012

15. Bahal A, Karamchandani D, AP F, ML M. Hand Hygiene Compliance: Universally better Post-Contact than Pre-
Contact in Healthcare Workers in the UK and Australia. $\mathrm{Br}$ J Infect Control. 2007;8(1):24-8.

16. Wendt C, Knautz D, Baum H von. Differences in Hand Hygiene Behavior Related to the Contamination Risk of Healthcare Activities in Different Groups of Healthcare Workers. 2004;25(3):203-6.

17. Allegranzi B, Pittet D. Role of Hand Hygiene in Healthcare-Associated Infection Prevention. J Hosp Infect [Internet]. 2009;73(4):305-15. Available from: http://dx.doi.org/10.1016/j.jhin.2009.04.019 doi: 10.1016/j.jhin.2009.04.019 